\title{
Epigenetic Associations between lncRNA/circRNA and miRNA in Hepatocellular Carcinoma
}

\author{
Tae-Su Han ${ }^{1,+}$, Keun Hur ${ }^{2,+}\left(\mathbb{D}\right.$, Hyun-Soo Cho ${ }^{1, *}$ (i) and Hyun Seung Ban ${ }^{1, *(1)}$ \\ Korea Research Institute of Bioscience and Biotechnology (KRIBB), Daejeon 34141, Korea; tshan@kribb.re.kr \\ 2 Department of Biochemistry and Cell Biology, School of Medicine, Kyungpook National University, \\ Daegu 41944, Korea; KeunHur@knu.ac.kr \\ * Correspondence: chohs@kribb.re.kr (H.-S.C.); banhs@kribb.re.kr (H.S.B.) \\ + These authors contributed equally to this work.
}

Received: 12 August 2020; Accepted: 13 September 2020; Published: 14 September 2020

Simple Summary: Non-coding RNAs such as microRNAs, long non-coding RNAs, and circular RNAs contribute to the development and progression of hepatocellular carcinoma through epigenetic association. Long non-coding RNAs and circular RNAs act as competing endogenous RNAs that contain binding sites for miRNAs and thus compete with the miRNAs, which results in promotion of miRNA target gene expression, thereby leading to proliferation and metastasis of hepatocellular carcinoma. Competing endogenous RNAs have the potential to become diagnostic biomarkers and therapeutic targets for treatment of hepatocellular carcinoma.

\begin{abstract}
The three major members of non-coding RNAs (ncRNAs), named microRNAs (miRNAs), long non-coding RNAs (lncRNAs), and circular RNAs (circRNAs), play an important role in hepatocellular carcinoma (HCC) development. Recently, the competing endogenous RNA (ceRNA) regulation model described lncRNA/circRNA as a sponge for miRNAs to indirectly regulate miRNA downstream target genes. Accumulating evidence has indicated that ceRNA regulatory networks are associated with biological processes in HCC, including cancer cell growth, epithelial to mesenchymal transition (EMT), metastasis, and chemoresistance. In this review, we summarize recent discoveries, which are specific ceRNA regulatory networks (lncRNA/circRNA-miRNA-mRNA) in HCC and discuss their clinical significance.
\end{abstract}

Keywords: microRNA; long non-coding RNA; circular RNA; competing endogenous RNA; hepatocellular carcinoma

\section{Introduction}

Hepatocellular carcinoma (HCC) is one of the most commonly diagnosed cancers and highly lethal malignancies. There have been 42,810 new cases and 30,160 deaths in the United States in 2020 [1]. Risk factors for HCC are hepatitis B virus (HBV) or hepatitis C virus (HCV) infection, alcohol consumption, nonalcoholic fatty liver disease (NAFLD), non-alcoholic steatohepatitis (NASH), and hereditary diseases [2-7]. HCC patients are treated with potentially curative resection in approximately $30-40 \%$ of cases; however, these patients still have a poor prognosis because of the high frequency of metastasis and recurrence [8-10]. During HCC progression, cellular changes, including inflammation, hypoxia, and the tumor microenvironment are important as various molecular events can occur. There are major signal transduction pathways that promote HCC, including Myc, MAPK, PI3K, WNT, and JAK [11-14]. Despite these well-known signaling pathways, there is still inadequate information to understand HCC progression. Thus, novel target molecules are urgently required for the application of diagnostic biomarkers and therapeutic agents. 
Non-coding RNAs (ncRNAs) were traditionally considered "junk genes." Recently, various ncRNAs have been identified by developing next-generation sequencing techniques and found to play a critical role in the regulation of gene expression by binding to promoters or directly interacting with proteins [15-17]. Accumulating evidence has shown that ncRNAs are involved in normal cellular processes, but their dysregulation is associated with disease progression, including cancer [18,19]. Furthermore, dysregulated non-coding RNAs are associated with HCC initiation, progression, and metastasis [20].

Long ncRNAs are longer than 200 nucleotides, generally do not code for proteins, and function as master regulators. Numerous studies have revealed the biological contributions of lncRNAs as regulators of transcription, modulators of mRNA processing, and organization of nuclear domains [21,22]. However, dysregulated lncRNAs are involved in the pathological processes of cancers, including cell growth, survival, and differentiation by functioning as oncogenes or tumor suppressors $[23,24]$.

Circular RNAs are endogenous ncRNAs that lack $5^{\prime}$ and $3^{\prime}$ ends and are products of backsplicing on precursor mRNAs [25]. CircRNAs are evolutionarily conserved and have high stability because of their circular structure; thus, they are inherently resistant to RNase activity. In addition, several studies have shown that there are specific miRNA binding sites in circRNA sequences. Therefore, recent studies have focused on the ability of miRNA sponges to regulate gene expression. Furthermore, increasing evidence shows that aberrant expression of circRNAs can be mediated in cancer progression due to its important biological function, as a miRNA sponge [26,27].

Short ncRNAs include microRNA (miRNA), small interfering RNA (siRNA), snoRNA, rRNA, tRNA, and Piwi-interacting RNA (piRNA) [28,29]. Among them, most studies have focused on miRNAs. Most miRNAs are transcribed by RNA polymerase II; however, small groups of miRNAs are transcribed by polymerase III. Micro RNAs are single-stranded RNAs and play a role as negative gene regulators by base pairing to partially complementary sites on the target mRNA $3^{\prime}$-untranslated region (UTR) [30,31]. When miRNAs bind to target mRNAs, target genes undergo translation repression or decay (Figure 1) [32,33]. A single miRNA can regulate multiple targets containing specific miRNA response elements (MREs). In addition, a single RNA contains multiple MREs; therefore, multiple miRNAs can regulate a single RNA [34]. Abnormal expression of miRNAs can affect cancer development, including cell proliferation, angiogenesis, apoptosis, and cell motility [35-40]. Several researchers have found that molecular mechanisms influence carcinogenesis [41,42]. There are two types of miRNAs that play roles in cancer (including HCC), tumor suppressor miRNAs and onco-miRs [43-45].

In the past few years, most miRNA studies have focused on the unidirectional regulation of target transcripts; however, competitive miRNA binding has been observed using artificial miRNA sponges, which act as inhibitors of multiple miRNAs [46-48]. The first natural miRNA sponge was identified in Arabidopsis thaliana, in which it sequestered miR-399 and inhibited its activity by "target mimicry." Most miRNA targets are cleaved by miRNAs in plants owing to their almost perfect miRNA match. However, the miR-399 motif on IPS1 contains a mismatched loop at the miRNA binding site that eliminates cleavage. Therefore, IPS1 can act as a miR-399 sponge and change the stability of its target, PHO2 mRNA [49,50]. In animal cells, Ebert et al. observed similar phenomena: artificial overexpression of miRNA binding sites leads to upregulation of miRNA targets acting as RNA sponges [51]. Since 2011, this kind of post-transcriptional regulation has been described by the "competing endogenous RNA (ceRNA)" model, which describes competitive binding between sponge RNA and miRNA target genes and regulation of miRNA target gene activity (Figure 2) [52]. Importantly, numerous studies have shown that lncRNAs or circRNAs can act as ceRNAs containing miRNA-binding sites. Therefore, miRNAs can be suppressed by increasing the stability of miRNA target mRNAs. Notably, this ceRNA mechanism has been discovered in diverse diseases, including multiple cancers $[53,54]$. 


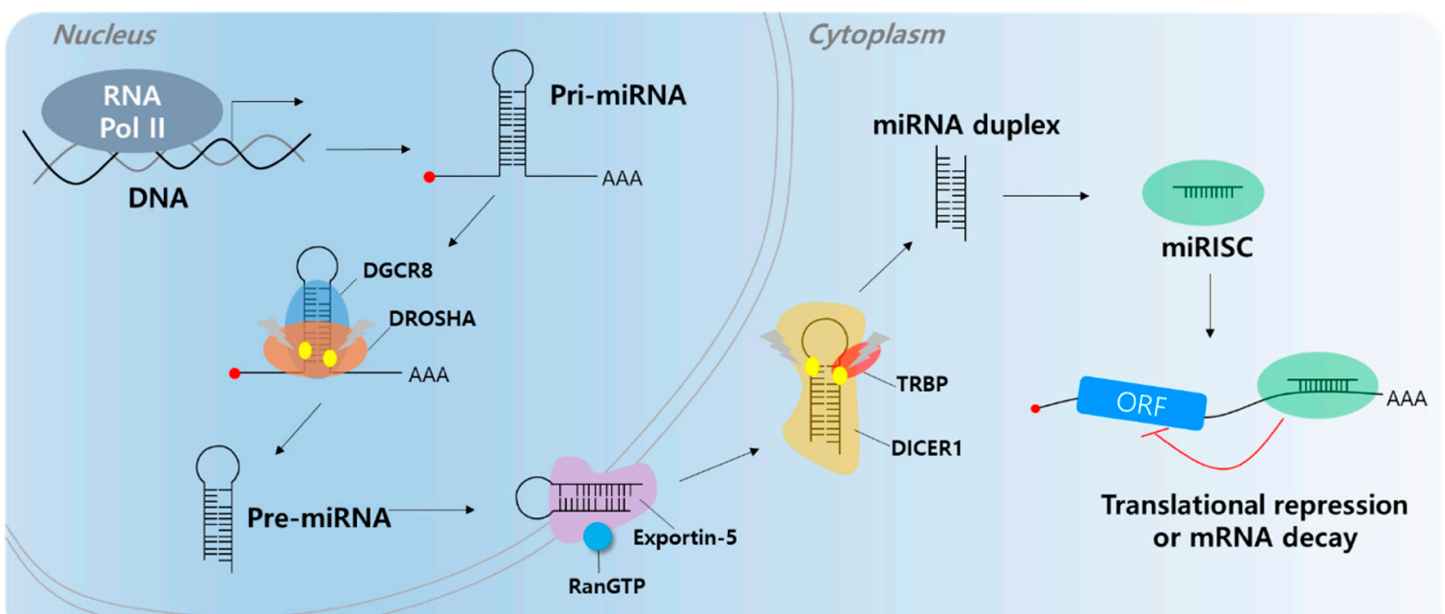

Figure 1. MicroRNA biogenesis. The primary miRNA (pri-miRNA) is transcribed by RNA polymerase II (RNA Pol II). The microprocessor complex, Drosha and DiGeorge Syndrome Critical Region 8 (DGCR8), cleaves the pri-miRNA to produce the precursor miRNA (pre-miRNA). The pre-miRNA translocates to the cytoplasm in an Exportin-5/RnaGTP-dependent manner. TAR RNA-binding protein (TRBP) and Dicer1 cleave the pre-miRNA to produce the mature miRNA duplex. The $5 p$ or $3 p$ of the miRNA duplex is loaded into the miRNA-induced silencing complex (miRISC). Finally, the miRISC binds to target mRNAs to induce translational repression or mRNA decay.
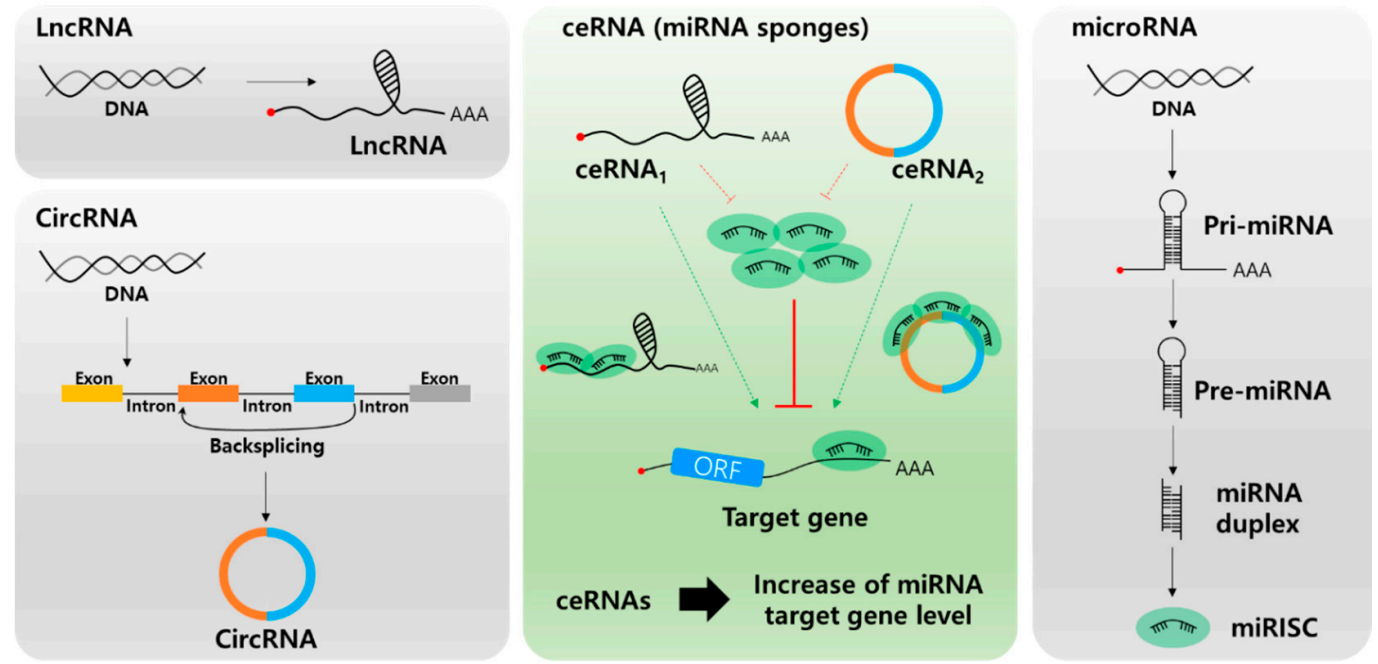

Figure 2. Biogenesis of long non-coding RNA (lncRNA, top left), circular RNA (circRNA, bottom left), microRNA (miRNA, right), and the role of lnc/circRNA as competing endogenous RNAs (ceRNAs, center). Different types of ceRNAs including lncRNA and circRNA regulate the miRNA target mRNA expression by competing for miRNA binding.

Understanding the role of ncRNAs in tumorigenesis is a major challenge in recent molecular oncology. Therefore, in this review, we introduce the mechanism of the ceRNA network between lncRNA/circRNAs and miRNAs and discuss its possible role in HCC progression.

\section{Long Non-Coding RNA and microRNA Networks in HCC}

Although most lncRNA functions are unknown, several functional studies have shown that they are closely associated with cancer progression. Growing evidence indicates that their tumorigenicity may be mediated by ceRNA regulatory mechanisms. In this section, we present the details of the regulatory network between miRNAs and lncRNAs in HCC from recent and prominent studies (Table 1). 
Table 1. Long non-coding RNA and microRNA networks in HCC.

\begin{tabular}{|c|c|c|c|c|}
\hline lncRNAs & Target miRNA & Target Genes of miRNA & Function & Reference \\
\hline \multicolumn{5}{|c|}{ Overexpression of lncRNAs in HCC } \\
\hline SNHG11 & miR-184 & AGO2 & $\begin{array}{l}\text { HCC proliferation, } \\
\text { migration, autophagy }\end{array}$ & [55] \\
\hline CCAT1 & let-7 & $H M G A 2, c-M Y C$ & $\begin{array}{l}\text { HCC proliferation, } \\
\text { migration }\end{array}$ & [56] \\
\hline SNHG16 & let-7b-5p & $C D C 25 B$ & $\begin{array}{c}\text { Cell cycle, } \\
\text { migration/invasion }\end{array}$ & [57] \\
\hline HOXA-AS2 & $\operatorname{miR}-520 c-3 p$ & GPC3 & $\begin{array}{l}\text { Cell cycle, apoptosis, } \\
\text { migration/invasion }\end{array}$ & [26] \\
\hline CDKN2B-AS1 & let-7c-5p & NAP1L1 & $\begin{array}{l}\text { Cell cycle, apoptosis, } \\
\text { migration/invasion }\end{array}$ & [58] \\
\hline FEZF1-AS1 & $\operatorname{miR}-4443$ & & $\begin{array}{l}\text { HCC proliferation, } \\
\text { metastasis }\end{array}$ & [59] \\
\hline H19 & miR-326 & TWIST & $\begin{array}{l}\text { HCC proliferation, } \\
\text { metastasis }\end{array}$ & [60] \\
\hline MALAT1 & $\begin{array}{l}\text { miR-30a-5p } \\
\text { miR-146b-5p }\end{array}$ & $\begin{array}{l}\text { Vimentin } \\
\text { TRAF6 }\end{array}$ & $\begin{array}{l}\text { HCC proliferation, } \\
\text { metastasis }\end{array}$ & $\begin{array}{l}{[61]} \\
{[62]}\end{array}$ \\
\hline FOXD2-AS1 & miR-206 & ANXA2 & $\begin{array}{l}\text { HCC proliferation, } \\
\text { metastasis }\end{array}$ & [63] \\
\hline TINCR & miR-214-5p & ROCK1 & $\begin{array}{l}\text { HCC proliferation, } \\
\text { metastasis }\end{array}$ & [64] \\
\hline SNHG15 & miR-490-3P & HDAC2 & $\begin{array}{l}\text { HCC proliferation, } \\
\text { metastasis }\end{array}$ & [65] \\
\hline SNHG8 & miR-149-5p & PPM1F & $\begin{array}{l}\text { HCC proliferation, } \\
\text { metastasis }\end{array}$ & [66] \\
\hline FLVCR1-AS1 & $\operatorname{miR}-513 c$ & MET & $\begin{array}{l}\text { HCC proliferation, } \\
\text { metastasis }\end{array}$ & [67] \\
\hline ROR & miR-145 & ZEB2 & HCC metastasis & {$[68]$} \\
\hline LINC00460 & $\operatorname{miR}-485-5 p$ & PAK1 & $\begin{array}{l}\text { HCC proliferation, } \\
\text { angiogenesis }\end{array}$ & [69] \\
\hline LINC00488 & miR-330-5p & TLN1 & HCC proliferation & {$[70]$} \\
\hline DSCR8 & miR-485-5p & FZD7 & $\begin{array}{c}\text { Wnt } / \beta \text {-catenin signaling } \\
\text { pathway }\end{array}$ & [71] \\
\hline DBH-AS1 & $\operatorname{miR}-138$ & & FAK/Src/ERK pathway & [72] \\
\hline TUG1 & miR-144 & & JAK2/STAT3 pathway & [73] \\
\hline SNHG12 & $\operatorname{miR}-199 a / b-5 p$ & $M L K 3$ & NF-kB pathway & [74] \\
\hline SNHG6-003 & $\mathrm{miR}-26 \mathrm{a} / \mathrm{b}$ & TAK1 & p38 pathway & [75] \\
\hline UCA1 & miR-216b & FGFR1 & $\begin{array}{c}\text { FAFR1/ERK signaling } \\
\text { pathway }\end{array}$ & [76] \\
\hline NEAT1 & $\operatorname{miR}-204$ & ATG3 & HCC autophagy process & [77] \\
\hline CCAT1 & miR-181a-5p & ATG7 & HCC autophagy process & [78] \\
\hline PVT1 & $\operatorname{miR}-365$ & ATG3 & HCC autophagy process & [79] \\
\hline MIAT & $\begin{array}{l}\text { miR-22-3P } \\
\text { miR-520d-3p }\end{array}$ & $\begin{array}{c}\text { SIRT1 } \\
\text { EPHA2 }\end{array}$ & $\begin{array}{c}\text { Cellular senescence } \\
\text { HCC proliferation, } \\
\text { metastasis }\end{array}$ & $\begin{array}{l}{[80]} \\
{[81]}\end{array}$ \\
\hline \multicolumn{5}{|c|}{ Downregulation of lncRNAs in HCC } \\
\hline GAS5 & miR-21 & PTEN & Tumor suppressor & [82] \\
\hline SNHG16 & has-miR-93 & & $\begin{array}{c}\text { Tumor suppressor, 5-FU } \\
\text { chemoresistance }\end{array}$ & [83] \\
\hline XIST & miR-497-5p & PDCD4 & Tumor suppressor & [84] \\
\hline EPB41L4A-AS2 & miR-301a-5p & FOXL1 & Tumor suppressor & [85] \\
\hline DGCR5 & $\operatorname{miR}-346$ & KLF14 & Tumor suppressor & [86] \\
\hline MIR31HG & miR-575 & $S T 7 L$ & Tumor suppressor & [87] \\
\hline LINC00657 & miR-106a-5p & PTEN & Tumor suppressor & [88] \\
\hline TUSC7 & miR-10a & EPHA4 & Tumor suppressor & [89] \\
\hline
\end{tabular}

2.1. Overexpression of $\operatorname{lncRNAs}$ Promotes HCC Proliferation and Metastasis via Sponging of Tumor Suppressing miRNAs

In a lncRNA microarray assay, SNHG11 was overexpressed and associated with poor prognosis in HCC. To regulate HCC proliferation, SNHG11 was negatively regulated by miR-184, which directly targets AGO2. In HCC tissues, SNHG11 was negatively correlated with miR-184 and positively correlated with AGO2 expression [55]. The lncRNA CCAT1 was overexpressed in HCC tissues and sponged miRNA let-7 leading to upregulation of HMGA2 and $c-M Y C$ expression [56]. To regulate the cell cycle, lncRNA SNHG16 absorbed miRNA let-7b-5p, and SNHG16 promoted the G2/M transition via regulation of the let-7b-5p/CDC25B axis [57]. In addition, knockdown of lncRNAs HOXA-AS2 and CDKN2B-AS1 induced cell apoptosis via G1 arrest. HOXA-AS2 sponged miR-520c-3p and let-7c-5p, 
and upregulated GPC3 and NAP1L1 expression by downregulating miR-520c-3p and let-7c-5p [26,58]. In addition, overexpression of FEZF1-AS1 and H19 in HCC sponged miR-4443 and miR-326 leading to HCC growth and metastasis, respectively. MiR-326 directly targeted the transcription factor TWIST. Subsequently, downregulation of miR-326 by H19 induced TWIST expression leading to HCC development and metastasis [59,60].

In HCC metastasis, high levels of MALAT1 and FOXD2-AS1 increase vimentin and ANXA2 expression by sponging miR-30a-5p and miR-206, respectively. In a migration/wound healing assay, siMALAT1 and siFOXD2-AS1 treatment reduced the migration and wound healing rate compared to the siNegative control by reduction of TWIST1/ANXA2 expression and upregulation of miR-30a-5p and miR-206 [61,63]. In addition, IncRNA MALAT1 sponged miR-146b-5p to induce TRAF6 expression leading to HCC metastasis [62]. Moreover, lncRNA TINCR is a sponge for miR-214-5p. TINCR overexpression sponged miR-214-5p to upregulate ROCK1 in HCC metastasis [64]. Knockdown of lncRNA SNHG15 and SNHG8 suppressed HCC metastasis and proliferation via regulation of the miR-490-3P/ HDAC2 axis and miR-149-5p/ PPM1F axis, respectively. HDAC2 and PPM1F were direct targets of miR-490-3P and miR-149-5p, and overexpression of SNHG15 and SNHG8 in HCC showed a correlation between HDAC2 and PPM1F expression via the absorption of miR-490-3P and miR-149-5p, respectively $[65,66]$. The lncRNA FLVCR1-AS1 sponged miR-513c to modulate HCC metastasis and proliferation via up-regulation of $M E T$ expression [67]. In addition, overexpression of lncRNA ROR induced ZEB2 expression by sponging miR-145, and increased EMT and HCC metastasis [68]. The lncRNA MIAT sponged miR-520d-3p, upregulating EPHA2 expression leading to HCC proliferation and metastasis [81]. In addition, knockdown of LINC00460 and LINC00488 induced cell apoptosis and reduced angiogenesis via downregulation of PAK1 and TLN1, respectively, which are direct targets of miR-485-5p and miR-330-5p. LINC00460 and LINC00488 sponged miR-485-5p and miR-330-5p leading to HCC tumorigenesis and angiogenesis, respectively $[69,70]$.

To regulate the HCC signaling pathway, lncRNA DSCR8 acts as a sponge for miR-485-5p and regulates the $\mathrm{Wnt} / \beta$-catenin signaling pathway resulting in upregulation of $F Z D 7$. Statistical analysis of DSCR8 and miR-485-5p showed a close relationship between malignant clinicopathological features and survival rate [71]. In addition, IncRNAs DBH-AS1 and TUG1 up-regulated the FAK/Src/ERK and JAK2/STAT3 pathways by sponging miR-138 and miR-144 resulting in HCC tumorigenesis [72,73]. The lncRNAs SNHG12 and SNHG6-003 upregulated the NF-KB and p38 pathways via induction of MLK3 and TAK1 expression by sponging miR-199a/b-5p and miR-26a/b, respectively [74,75]. Moreover, lncRNA UCA1 activated the FAFR1/ERK signaling pathway by regulating FGFR1 expression by sponging miR-216b [76].

During autophagy, upregulation of lncRNAs NEAT1 and CCAT absorbed miR-204 and miR-181a-5p to induce HCC autophagy via upregulation of ATG3 and ATG7, respectively [77,78]. In addition, lncRNA PVT1 induced HCC autophagy via regulation of the miR-365/ATG3 axis. Overexpression of PVT1 sponged miR-365 in HCC; consequently, ATG3 expression was increased by HCC autophagy induction [79].

Moreover, lncRNA MIAT is associated with senescence in HCC. Knockdown of MIAT induced cellular senescence and HCC growth. The target of miR-22-3P is Sirtuin 1 (SIRT1), and overexpression of MIAT downregulated miR-22-3P via the sponge effect, and SIRT1 expression increased. Downregulation of MIAT resulted in senescence-associated secretory phenotype and suppressed HCC tumorigenesis [80]. Overall, overexpressed lncRNAs are critically involved in HCC proliferation and metastasis via regulation of the cell cycle, autophagy, apoptosis, and several signaling pathways. Thus, overexpressed lncRNAs are recognized as HCC biomarkers and therapeutic targets.

\subsection{Tumor Suppressor IncRNAs Inhibit HCC Tumorigenesis by Sponging Onco-miRNAs}

In HCC cell lines and tissues, lncRNA GAS5 expression decreased. Knockdown of GAS5 induced doxorubicin resistance and promoted cell proliferation via upregulation of PTEN. Although miR-21 directly downregulated PTEN expression in HCC, overexpression of GAS5 was sponged by miR-21. Consequently, 
PTEN expression increased and inhibited HCC [82]. In addition, lncRNA SNHG16 overexpression inhibited HCC proliferation and 5-fluorouracil (5-FU) chemoresistance in in vivo/in vitro assays via absorption of has-miR-93 in Hep3B and Huh7 cell lines [83]. The lncRNA XIST was downregulated in HCC. Upregulation of miR-497-5p inhibits the expression of PDCD4 (programmed cell death 4). In a cell growth assay, overexpression of XIST inhibited the growth of HepG2 cell lines via upregulation of PDCD4 and absorption of miR-497-5p [84]. Downregulation of lncRNA EPB41L4A-AS2 in HCC is clearly associated with negative regulation of HCC proliferation and metastasis. Overexpression of EPB41L4A-AS2 sponged miR-301a-5p and inhibited cell growth and migration/invasion via upregulation of FOXL1 by miR-301a-5p downregulation. In an in vivo study, EPB41L4A-AS2 suppressed lung metastasis via regulation of the miR-301a-5p/FOXL1 axis [85]. The expression of lncRNAs DGCR5 and MIR31HG was negatively correlated with HCC proliferation and metastasis. Overexpression of DGCR5 and MIR31HG sponged miR-346 and miR-575, and suppressed HCC cell growth and migration/invasion via upregulation of KLF14 and ST7L expression, respectively [86,87]. In addition, LINC00657 and TUSC7 were positively correlated with PTEN and EPHA4 expression in HCC. Overexpression of LINC00657 and TUSC7 suppressed HCC proliferation, migration, and invasion by sponging of miR-106a-5p and miR-10a, and upregulation of PTEN and EPHA4 expression [88,89]. Collectively, the study of tumor suppressor lncRNAs in HCC helps to provide an understanding of HCC proliferation and metastasis, and lncRNAs can be used as potential biomarkers for HCC diagnosis.

\section{Circular RNA and microRNA Networks in HCC}

An increasing number of studies have revealed that circRNAs play important roles in cancer development, including HCC. CircRNA can be used as a ceRNA to decrease cytoplasmic levels of target miRNAs by abolishing miRNAs. Thus, gene expression levels of target mRNAs can be maintained. In this section, we describe how individual circRNAs may participate as ceRNAs in the regulatory network of HCC.

\subsection{Overexpression of Circrnas Induces HCC Progression by Sponging Tumor-Suppressive miRNAs}

To date, several studies have found that circRNAs exert oncogenic effects by sponging miRNAs in HCC progression. In HCC tissues and cell lines, circ-PVT1 derived from the PVT1 gene locus is markedly elevated and acts as a sponge of miR-3666 [90]. Knockdown of circ-PVT1 resulted in the reduction of proliferation and induction of apoptosis by upregulating miR-3666 in HCC cells. A molecular mechanism has been identified in which circ-PVT1 induces HCC proliferation by enhancing SIRT7, a target gene of miR-3666. In addition, various miRNAs including miR-125, miR-145, and miR-497 have been reported as sponge targets of circ-PVT1 in gastric cancer [91], colorectal cancer [92], and non-small cell lung cancer [93], respectively.

A study by Xiao et al. demonstrated that circRNA plays a role in the estrogen receptor (ER) $\alpha$-mediated decrease of HCC cell invasion [94]. ER $\alpha$ inhibited circ-SMG.172 expression by binding to the $5^{\prime}$ promoter region, and expression of the tumor suppressor miR-141-3p increased by disruption of the sponging function of circ-SMG.172. miR-141-3p subsequently suppressed the expression of Gelsolin by binding to the mRNA 3'UTR. In HBV-related HCC, circ-100338 also acts as a sponge for miR-141-3p [95]. In silico analysis suggests that MTSS1 is a potential target of miR-141-3p that regulates metastasis of HCC.

A bioinformatics analysis study found that upregulated circRNA and downregulated miRNA in HCC provided information about miRNA sponging circRNA [96]. From the qRT-PCR validation, has-circ-0009910 was found to be a sponge of miR-1261, which resulted in the enhancement of UBE2L3 expression and HCC progression.

In the early stages of HCC, various circRNAs have been identified as important regulators involved in HCC progression. Circ-CDYL is upregulated in early stage HCC and induces expression of HDGF and HIF1AN by sponging miR-892a and miR-328-3p, respectively [97]. Circ-CDYL-induced HDGF activates PI3K-AKT signaling by binding to its receptor NCL, which results in enhanced expression of 
c-MYC and survivin. Circ-CDYL-mediated HIF1AN also upregulates survivin expression via inhibition of Notch2 signaling.

In HCC cells, circ-PRKCI functions as a miRNA-545 sponge and disrupts its inhibitory activity against the E2F transcription factor 7 (E2F7) [98]. Higher expression of $E 2 F 7$ is observed in HCC and correlated with a lower survival rate. In HCC, enhanced expression of has-circ-0078710 is correlated with the promotion of cell proliferation, migration, and invasion. It was found that has-circ-0078710 functions as a sponge of miR-31, which results in the induction of HDAC and CDK2 target genes [99]. In HCC tissues, the upregulated expression of circ-001569 and circ-0005075 is correlated with increased HCC proliferation and metastasis. It was hsown that circ-001569 and circ- 0005075 act as sponges of miR-411-5p and miR-432-5p [100], and miR-431 [101], respectively. However, their target genes in HCC have not been mentioned.

A study by Bai et al. reported that circ-FBLIM1 functions as a competing endogenous RNA (ceRNA) to induce HCC progression [102]. The molecular mechanism is such that circ-FBLIM1 is the sponge of miR-346, and FBLIM1 is a direct target of miR-346. In HCC, overexpression of aquaporin 3 (AQP3) promotes cell proliferation and migration, and circ-HIPK3 expression is positively correlated with $A Q P 3$ expression by sponging miR-124 [103]. Knockdown of circ-HIPK3 reduced tumor growth via the miR-124-AQP3 axis in the Huh7 xenograft model. Therefore, these circRNAs functioning as sponges for mi-RNAs could be used as a biomarker for diagnosis and as targets for HCC therapy. The circRNAs, miRNAs, and their target genes are summarized in Table 2.

Table 2. Circular RNA and microRNA networks in HCC.

\begin{tabular}{|c|c|c|c|c|}
\hline CircRNAs & Target miRNA & Target Genes of miRNA & Function & Reference \\
\hline \multicolumn{5}{|c|}{ Overexpression of lncRNAs in HCC } \\
\hline circ-PVTa & $\mathrm{miR}-3666$ & SIRTUIN 7 & HCC proliferation & [90] \\
\hline circ-SMG1.72 & miR-141-3p & GELSOLIN & HCC invasion & [94] \\
\hline circ-100338 & miR-141-3p & MTSS1 & $\begin{array}{l}\text { hepatitis B-related } \\
\text { HCC progression }\end{array}$ & [95] \\
\hline has-circ-0009910 & miR-1261 & $U B E 2 L 3$ & HCC progression & [96] \\
\hline circ-CDYL & $\begin{array}{l}\text { miR-892a, } \\
\text { miR-328-3p }\end{array}$ & HDGF, HIF1AN & $\begin{array}{l}\text { Early stage HCC } \\
\text { progression }\end{array}$ & [97] \\
\hline circ-PRKCI & miRNA-545 & E2F7 & HCC proliferation & [98] \\
\hline has-circ-0078710 & $\operatorname{miR}-31$ & $H D A C, C D K 2$ & HCC progression & [99] \\
\hline circ-001569 & $\begin{array}{l}\text { miR-411-5p } \\
\text { miR-432-5p }\end{array}$ & unknown & $\begin{array}{l}\text { HCC proliferation, } \\
\text { metastasis }\end{array}$ & [100] \\
\hline has-circ-0005075 & miR-431 & unknown & $\begin{array}{c}\text { HCC proliferation, } \\
\text { metastasis }\end{array}$ & {$[101]$} \\
\hline circ-FBLIM1 & miR-346 & FBLIM1 & HCC progression & [102] \\
\hline circ-HIPK3 & miR-124 & $A Q P 3$ & $\begin{array}{l}\text { HCC proliferation, } \\
\text { metastasis }\end{array}$ & [103] \\
\hline \multicolumn{5}{|c|}{ Downregulation of lncRNAs in HCC } \\
\hline has-circ-0000204 & miR-191 & KLF6 & HCC proliferation & [104] \\
\hline circ-HIAT1 & miR-3171 & PTEN & HCC proliferation & [105] \\
\hline $\begin{array}{c}\text { circ-SETD3 } \\
\text { (has-circ-0000567) }\end{array}$ & $\operatorname{miR}-421$ & MAPK14 & HCC proliferation & [106] \\
\hline circ-ADAMTS13 & $\operatorname{miR}-484$ & unknown & HCC proliferation & [107] \\
\hline circ-MTO1 & miR-9 & $P 21$ & HCC progression & [108] \\
\hline has-circ-0005986 & miR-129-5p & NOTCH1 & HCC biomarker & [109] \\
\hline
\end{tabular}

\subsection{Tumor Suppressor Circrnas Inhibit HCC Tumorigenesis by Sponging Onco-miRNAs}

Several circRNAs that function as tumor suppressors in HCC have been reported. A study on HCC tumorigenesis found that circRNA is involved in the regulatory mechanism of oncogenic miR-191 [104]. In HCC Hep3B and HepG2 cells, elevated miR-191 was sponged by has-circ-0000204, and the expression of tumor suppressor KLF6 increased via binding reduction of miR-191 to the 3'UTR region of KLF6 mRNA. 
A study by Wang et al. reported the roles of circRNA hippocampus abundant transcript 1 (circ-HIAT1) in HCC and its tumor suppressive mechanism [105]. In vitro and in vivo experiments demonstrated that circ-HIAT1-mediated upregulation of PTEN expression via miR-3171 sponging resulted in HCC cell proliferation.

In HCC tissues, circ-SETD3 is another tumor suppressive circRNA that acts as a sponge of miRNA. Circ-SETD3 reduces the proliferation of Huh7 HCC cells by sponging miR-421 and enhancing expression of its target gene, MAPK14 [106]. In addition, overexpression of circ-SETD3 reduced tumor growth in a Huh7 xenograft mouse model.

circ-ADAMTS13 has also been identified as a tumor suppressor circRNA, and acts as a sponge of miR-484; however, its target gene is unknown [107]. Circ-MTO1 is another tumor suppressive circRNA that acts as a sponge of miRNA in HCC. Circ-MTO1 inhibits HCC progression by sponging oncogenic miR-9 to promote target gene $p 21$ expression [108]. Has-circ-0005986 exerts tumor suppressive effects by sponging miR-129-5p in HCC cell lines. Gene ontology analysis demonstrated that Notch1 is the direct target gene of miR-129-5p [109]. These studies suggest that circRNAs function as tumor suppressors and by sponging oncogenic miRNA, might be good HCC biomarkers. Tumor suppressive circRNAs and target miRNAs are listed in Table 2.

\section{Clinical Application of lncRNAs and CircRNAs as Novel Biomarkers in HCC}

As described above, IncRNAs/circRNAs, as ceRNAs, are heavily involved in HCC development via diverse regulation of onco-miRNAs and/or tumor suppressive-miRNAs (Figure 3). Increasing evidence indicates that ceRNAs not only serve as biomarkers for the diagnosis of various cancers, including HCC, but are also involved in chemotherapy resistance. Through meta-analysis, several studies have demonstrated the diagnostic value of IncRNAs as biomarkers in HCC [110]. Another group has analyzed lncRNA and mRNA expression profiles obtained from The Cancer Genome Atlas and identified four lncRNAs (RP11-486O12.2, RP11-863K10.7, LINC01093, and RP11-273G15.2) that have a diagnostic potential for HCC [111]. GAS5 is a novel non-Ig partner of BCL6. Suppression of GAS5 is associated with clinicopathological characteristics in several liver dysfunctions [112-114]. Tumor node stage (TNM), overall survival (OS), disease-free survival (DFS), and metastasis were correlated with GAS5 expression, indicating that GAS5 can be a potential diagnostic and prognostic biomarker in HCC [115]. HULC (highly upregulated in liver cancer) is known to reduce the expression of protein kinase cAMP-activated catalytic subunit beta (PRKACB) and to increase the HMGA2 oncogene via interaction with miR-372 and miR-186 in HCC [116,117]. In clinical analysis, HULC was detected more frequently in HCC patients with HBV, which was correlated with tumor size and tumor capsular invasion [118]. The plasma expression level of MALAT1 in HCC patients was associated with liver damage and showed clinical potential for predicting HCC development [119]. In addition, the serum level of UCA1 was higher in HCC patients [120]. Receiver operating characteristic (ROC) curve analysis revealed that serum UCA1 levels could distinguish HCC patients from healthy controls $(A U C=0.902)$ with high sensitivity and specificity. However, in order to apply this criterion clinically, additional evaluations are required. GALAD (which includes gender, age, AFP-L3, alpha-fetoprotein, and des-carboxy-prothrombin) and BALAD (which includes bilirubin, albumin, AFP-L3, alpha-fetoprotein, and des-carboxy-prothrombin) score calculations may be particularly useful [121,122].

As circRNAs are abundant, stable, and highly conserved, they have great potential as cancer diagnostic biomarkers in HCC. Previously, Shang et al. discovered 26 upregulated and 35 downregulated circRNAs in HCC tissues compared to adjacent non-tumorous tissues [123]. Among these 61 differentially expressed circRNAs, only hsa_circ_0005075 displayed differences in HCC, which correlated with tumor size and poor prognosis and exhibited good diagnostic potential $($ AUROC $=0.94)[123,124]$. In addition, differentially expressed hsa_circ_0004018 and hsa_circ_0128298 were identified in HCC by circRNA microarray $[125,126]$. After further validation via qRT-PCR, these two circRNAs showed strong potential as novel diagnostic and prognostic biomarkers in HCC 
patients. More recently, 13,124 circRNAs were identified in HBV-associated liver cancer patients using bioinformatics tools after high-throughput RNA sequencing [127]. Prediction analysis for circRNA-miRNA interactions revealed that 6020 circRNAs had putative binding sites for 1654 miRNAs. One of the identified circRNAs was circRNA_10156, which is up-regulated in liver cancer and leads to enhanced Akt1 expression via miR-149-3p sponging. Therefore, circRNA_10156 may be a useful biomarker for HBV-related liver cancer diagnosis.

\section{Inc and circ RNAs}

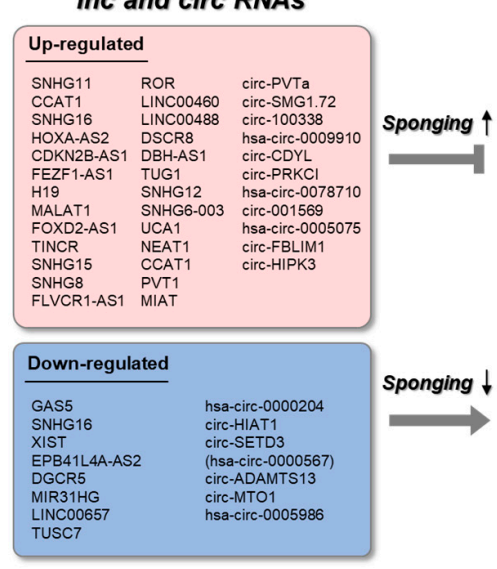

\section{Target miRNAs}

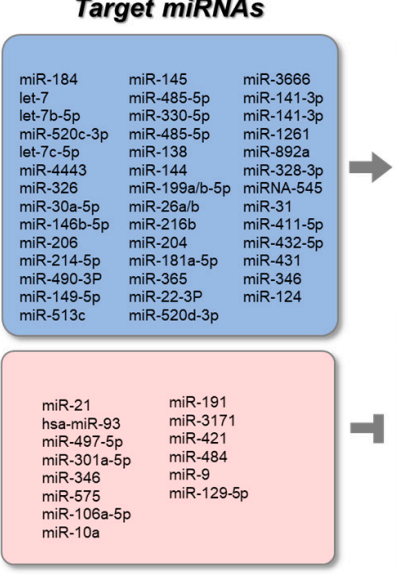

\section{Target genes}

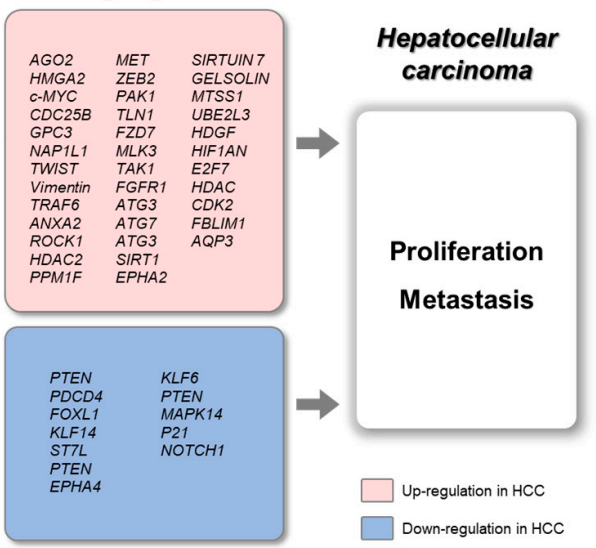

Figure 3. Schematic representation of lnc/circRNAs serving as ceRNAs in HCC. The upregulated long non-coding RNAs (lncRNAs) and circular RNAs (circRNAs) sponge target microRNAs (miRNAs), which results in increased expression of target genes. The downregulated lncRNAs and circRNAs sponge target miRNAs, which results in decreased expression of target genes.

Owing to their high stability and abundance, circRNAs in several body fluids such as blood, urine, and saliva, are considered suitable biomarkers for liquid biopsies [128]. Although alpha-fetoprotein (AFP) is the most widely used serum/plasma biomarker for HCC diagnosis, it has limitations for poor sensitivity and specificity [129]. First, Li et al. characterized circRNAs using RNA-seq analyses of MHCC-LM3 liver cancer cells and cell-derived exosomes [130]. In total, 6751 circRNAs were found in cell-derived exosomes. This number is at least two-fold higher in exosomes compared to that in the donor cells. Moreover, exosomal circRNA_100284 was found in the serum of arsenite-exposed patients [131]. Further functional analysis revealed that exosomal circRNA_100284, derived from malignant-transformed L-02 cells after arsenite exposure enhanced cell cycle and proliferation of normal liver cells and induced malignant transformation of non-transformed cells by acting as a sponge for miRNA-217. In addition, Wang et al. identified exosomal circPTGR1 in a metastatic liver cancer cell line, LM3, which promotes hepatocellular carcinoma metastasis via the miR449a-MET pathway [132]. Notably, some studies demonstrated that adipose-derived exosomal circRNA, circ-DB, promotes HCC cell growth and reduces DNA damage by suppressing miR-34a and activating the USP7/Cyclin A2 signaling pathway [133]. Thus, capitalizing on the high stability and tissue-specificity of exosomal circRNAs, might provide promising cancer biomarkers for early diagnosis and prognosis in HCC patients.

Accumulating evidence has revealed the involvement of ncRNAs in HCC chemo-drug resistance. Sorafenib targeting multiple receptor tyrosine kinases (RTKs) is currently an effective first-line therapy for HCC. However, sorafenib resistance is frequently observed during HCC treatment [134]. The lncRNA TUC338 has been known to be involved in the development of HCC and sorafenib resistance [135]. Enhanced TUC338 expression was observed in both HCC tissues and cell lines. Sorafenib silenced TUC338 in sensitized HepG2 HCC cells, which was accompanied by increased expression of RASAL1. Inversely, intratumoral delivery of siTUC338 could also restore the sorafenib treatment response in HepG2/Sor xenografts in vivo. Moreover, extracellular vesicle-enriched linc-VLDLR is also involved in sorafenib resistance of HCC cells [136]. Depletion of linc-VLDLR led to a reduction of the drug-resistant 
protein ABCG2 (ATP-binding cassette, subfamily G member 2), which resulted in the suppression of HCC cell proliferation and cell cycle arrest in G1/S. However, elevation of ABCG2 protein inhibited sorafenib-induced cell death by VLDLR knockdown. Recently, aberrant expression of circRNAs has also been identified in sorafenib-resistant HCC cells [137]. Based on high-throughput RNA-sequencing and analysis with CIRI (V2.0) software [138,139], 1,717 and 582 differentially expressed circRNAs were identified in sorafenib-resistant Huh7-S and HepG2-S HCC cells compared to parental HCC cells, respectively. In further gene ontology and pathway analyses, downregulated hsa_circ_0006294 and hsa_circ_0035944 expression was observed in sorafenib-resistant HCC cells.

\section{Conclusions}

In this review, we describe lncRNAs/circRNAs as sponges for regulating miRNAs and their target genes in HCC. We highlight examples of ncRNAs participating in regulatory networks and how they contribute to cancer malignancy. However, the understanding of ceRNA network regulation in the ncRNA field in HCC remains limited, because many HCC-related miRNAs and ncRNAs have not been identified. Therefore, further studies are necessary to elucidate the functions and mechanisms of HCC-related ceRNAs. Furthermore, the lncRNA, circRNA, miRNA, and miRNA target mRNAs involved in the ceRNA network can be potential therapeutic targets and diagnostic markers for HCC. Results from studies on ncRNAs in cancer are very promising. However, classic biomarkers and derived scores continue to be used as a golden standard in the early detection of HCC. Therefore, large prospective studies for the validation of diagnosis using ncRNA biomarkers should be conducted.

Author Contributions: H.-S.C. and T.-S.H.; writing-original draft preparation, K.H.; writing-review and editing, H.S.B.; writing - editing and visualization. All authors have read and agreed to the published version of the manuscript.

Funding: This study was supported by grants from the National Research Foundation of Korea (NRF) funded by the Ministry of Science and ICT (NRF-2019R1A2C1083892, NRF-2017M3A9G8083382, NRF-2018M3A9H3023077, NRF-2019R1I1A2A01060951, NRF-s2020R1C1C1007431) and the KRIBB Research Initiative Program.

Conflicts of Interest: The authors declare no conflict of interest.

\section{References}

1. Siegel, R.L.; Miller, K.D.; Jemal, A. Cancer statistics, 2020. CA Cancer J. Clin. 2020, 70, 7-30. [CrossRef] [PubMed]

2. Parikh, S.; Hyman, D. Hepatocellular cancer: A guide for the internist. Am. J. Med. 2007, 120, $194-202$. [CrossRef] [PubMed]

3. Liu, C.J.; Kao, J.H. Hepatitis B virus-related hepatocellular carcinoma: Epidemiology and pathogenic role of viral factors. J. Chin. Med. Assoc. 2007, 70, 141-145. [CrossRef]

4. Turati, F.; Galeone, C.; Rota, M.; Pelucchi, C.; Negri, E.; Bagnardi, V.; Corrao, G.; Boffetta, P.; La Vecchia, C. Alcohol and liver cancer: A systematic review and meta-analysis of prospective studies. Ann. Oncol. 2014, 25, 1526-1535. [CrossRef] [PubMed]

5. Younossi, Z.M.; Koenig, A.B.; Abdelatif, D.; Fazel, Y.; Henry, L.; Wymer, M. Global epidemiology of nonalcoholic fatty liver disease-Meta-analytic assessment of prevalence, incidence, and outcomes. Hepatology 2016, 64, 73-84. [CrossRef]

6. Yu, M.W.; Lin, C.L.; Liu, C.J.; Yang, S.H.; Tseng, Y.L.; Wu, C.F. Influence of Metabolic Risk Factors on Risk of Hepatocellular Carcinoma and Liver-Related Death in Men With Chronic Hepatitis B: A Large Cohort Study. Gastroenterology 2017, 153, 1006-1017. [CrossRef]

7. Torres, H.A.; Shigle, T.L.; Hammoudi, N.; Link, J.T.; Samaniego, F.; Kaseb, A.; Mallet, V. The oncologic burden of hepatitis C virus infection: A clinical perspective. CA Cancer J. Clin. 2017, 67, 411-431. [CrossRef]

8. Nakagawa, S.; Wei, L.; Song, W.M.; Higashi, T.; Ghoshal, S.; Kim, R.S.; Bian, C.B.; Yamada, S.; Sun, X.; Venkatesh, A.; et al. Molecular Liver Cancer Prevention in Cirrhosis by Organ Transcriptome Analysis and Lysophosphatidic Acid Pathway Inhibition. Cancer Cell 2016, 30, 879-890. [CrossRef]

9. Parikh, N.D.; Singal, A.G.; Hutton, D.W. Cost effectiveness of regorafenib as second-line therapy for patients with advanced hepatocellular carcinoma. Cancer 2017, 123, 3725-3731. [CrossRef] 
10. Goossens, N.; Sun, X.; Hoshida, Y. Molecular classification of hepatocellular carcinoma: Potential therapeutic implications. Hepat. Oncol. 2015, 2, 371-379. [CrossRef]

11. Cao, Z.; Fan-Minogue, H.; Bellovin, D.I.; Yevtodiyenko, A.; Arzeno, J.; Yang, Q.; Gambhir, S.S.; Felsher, D.W. MYC phosphorylation, activation, and tumorigenic potential in hepatocellular carcinoma are regulated by HMG-CoA reductase. Cancer Res. 2011, 71, 2286-2297. [CrossRef] [PubMed]

12. Yang, P.M.; Liu, Y.L.; Lin, Y.C.; Shun, C.T.; Wu, M.S.; Chen, C.C. Inhibition of autophagy enhances anticancer effects of atorvastatin in digestive malignancies. Cancer Res. 2010, 70, 7699-7709. [CrossRef] [PubMed]

13. Sutter, A.P.; Maaser, K.; Hopfner, M.; Huether, A.; Schuppan, D.; Scherubl, H. Cell cycle arrest and apoptosis induction in hepatocellular carcinoma cells by HMG-CoA reductase inhibitors. Synergistic antiproliferative action with ligands of the peripheral benzodiazepine receptor. J. Hepatol. 2005, 43, 808-816. [CrossRef] [PubMed]

14. Hoshida, Y.; Fuchs, B.C.; Tanabe, K.K. Prevention of hepatocellular carcinoma: Potential targets, experimental models, and clinical challenges. Curr. Cancer Drug Targets 2012, 12, 1129-1159.

15. Eddy, S.R. Non-coding RNA genes and the modern RNA world. Nat. Rev. Genet. 2001, 2, 919-929. [CrossRef]

16. Uszczynska-Ratajczak, B.; Lagarde, J.; Frankish, A.; Guigo, R.; Johnson, R. Towards a complete map of the human long non-coding RNA transcriptome. Nat. Rev. Genet. 2018, 19, 535-548. [CrossRef]

17. Li, W.; Notani, D.; Rosenfeld, M.G. Enhancers as non-coding RNA transcription units: Recent insights and future perspectives. Nat. Rev. Genet. 2016, 17, 207-223. [CrossRef]

18. Anastasiadou, E.; Jacob, L.S.; Slack, F.J. Non-coding RNA networks in cancer. Nat. Rev. Cancer 2018, 18, 5-18. [CrossRef]

19. Slack, F.J.; Chinnaiyan, A.M. The Role of Non-coding RNAs in Oncology. Cell 2019, 179, 1033-1055. [CrossRef]

20. Wong, C.M.; Tsang, F.H.; Ng, I.O. Non-coding RNAs in hepatocellular carcinoma: Molecular functions and pathological implications. Nat. Rev. Gastroenterol. Hepatol. 2018, 15, 137-151. [CrossRef]

21. Quinn, J.J.; Chang, H.Y. Unique features of long non-coding RNA biogenesis and function. Nat. Rev. Genet. 2016, 17, 47-62. [CrossRef] [PubMed]

22. Yao, R.-W.; Wang, Y.; Chen, L.-L. Cellular functions of long noncoding RNAs. Nat. Cell Biol. 2019, $21,542-551$. [CrossRef] [PubMed]

23. Wang, X.; Sun, W.; Shen, W.; Xia, M.; Chen, C.; Xiang, D.; Ning, B.; Cui, X.; Li, H.; Li, X.; et al. Long non-coding RNA DILC regulates liver cancer stem cells via IL-6/STAT3 axis. J. Hepatol. 2016, 64, 1283-1294. [CrossRef] [PubMed]

24. Schmitt, A.M.; Chang, H.Y. Long Noncoding RNAs in Cancer Pathways. Cancer Cell 2016, 29, $452-463$. [CrossRef] [PubMed]

25. Li, X.; Yang, L.; Chen, L.L. The Biogenesis, Functions, and Challenges of Circular RNAs. Mol. Cell 2018, 71, 428-442. [CrossRef]

26. Yu, J.; Xu, Q.G.; Wang, Z.G.; Yang, Y.; Zhang, L.; Ma, J.Z.; Sun, S.H.; Yang, F.; Zhou, W.P. Circular RNA cSMARCA5 inhibits growth and metastasis in hepatocellular carcinoma. J. Hepatol. 2018, 68, 1214-1227. [CrossRef]

27. Zhang, X.; Wang, S.; Wang, H.; Cao, J.; Huang, X.; Chen, Z.; Xu, P.; Sun, G.; Xu, J.; Lv, J.; et al. Circular RNA circNRIP1 acts as a microRNA-149-5p sponge to promote gastric cancer progression via the AKT1/mTOR pathway. Mol. Cancer 2019, 18, 20. [CrossRef] [PubMed]

28. Huang, X.; Toth, K.F.; Aravin, A.A. piRNA Biogenesis in Drosophila melanogaster. Trends Genet. 2017, 33, 882-894. [CrossRef]

29. Kim, V.N.; Han, J.; Siomi, M.C. Biogenesis of small RNAs in animals. Nat. Rev. Mol. Cell Biol. 2009, 10, 126-139. [CrossRef]

30. Ha, M.; Kim, V.N. Regulation of microRNA biogenesis. Nat. Rev. Mol. Cell Biol. 2014, 15, 509-524. [CrossRef]

31. Bartel, D.P. MicroRNAs: Genomics, biogenesis, mechanism, and function. Cell 2004, 116, 281-297. [CrossRef]

32. Jonas, S.; Izaurralde, E. Towards a molecular understanding of microRNA-mediated gene silencing. Nat. Rev. Genet. 2015, 16, 421-433. [CrossRef] [PubMed]

33. Hausser, J.; Zavolan, M. Identification and consequences of miRNA-target interactions-Beyond repression of gene expression. Nat. Rev. Genet. 2014, 15, 599-612. [CrossRef]

34. Bassett, A.R.; Azzam, G.; Wheatley, L.; Tibbit, C.; Rajakumar, T.; McGowan, S.; Stanger, N.; Ewels, P.A.; Taylor, S.; Ponting, C.P.; et al. Understanding functional miRNA-target interactions in vivo by site-specific genome engineering. Nat. Commun. 2014, 5, 4640. [CrossRef] 
35. Bracken, C.P.; Scott, H.S.; Goodall, G.J. A network-biology perspective of microRNA function and dysfunction in cancer. Nat. Rev. Genet. 2016, 17, 719-732. [CrossRef] [PubMed]

36. Han, T.S.; Hur, K.; Xu, G.; Choi, B.; Okugawa, Y.; Toiyama, Y.; Oshima, H.; Oshima, M.; Lee, H.J.; Kim, V.N.; et al. MicroRNA-29c mediates initiation of gastric carcinogenesis by directly targeting ITGB1. Gut 2015, 64, 203-214. [CrossRef]

37. Han, T.S.; Voon, D.C.; Oshima, H.; Nakayama, M.; Echizen, K.; Sakai, E.; Yong, Z.W.E.; Murakami, K.; Yu, L.; Minamoto, T.; et al. Interleukin 1 Up-regulates MicroRNA 135b to Promote Inflammation-Associated Gastric Carcinogenesis in Mice. Gastroenterology 2019, 156, 1140-1155. [CrossRef]

38. Hwang, J.S.; Jeong, E.J.; Choi, J.; Lee, Y.J.; Jung, E.; Kim, S.K.; Min, J.K.; Han, T.S.; Kim, J.S. MicroRNA-1258 Inhibits the Proliferation and Migration of Human Colorectal Cancer Cells through Suppressing CKS1B Expression. Genes 2019, 10, 912. [CrossRef]

39. Law, P.T.; Qin, H.; Ching, A.K.; Lai, K.P.; Co, N.N.; He, M.; Lung, R.W.; Chan, A.W.; Chan, T.F.; Wong, N. Deep sequencing of small RNA transcriptome reveals novel non-coding RNAs in hepatocellular carcinoma. J. Hepatol. 2013, 58, 1165-1173. [CrossRef]

40. Sandbothe, M.; Buurman, R.; Reich, N.; Greiwe, L.; Vajen, B.; Gurlevik, E.; Schaffer, V.; Eilers, M.; Kuhnel, F.; Vaquero, A.; et al. The microRNA-449 family inhibits TGF-beta-mediated liver cancer cell migration by targeting SOX4. J. Hepatol. 2017, 66, 1012-1021. [CrossRef]

41. Peng, Y.; Croce, C.M. The role of MicroRNAs in human cancer. Signal Transduct. Target. Ther. 2016, 1, 15004. [CrossRef] [PubMed]

42. Jansson, M.D.; Lund, A.H. MicroRNA and cancer. Mol. Oncol. 2012, 6, 590-610. [CrossRef] [PubMed]

43. Han, T.S.; Ban, H.S.; Hur, K.; Cho, H.S. The Epigenetic Regulation of HCC Metastasis. Int. J. Mol. Sci. 2018, 19, 3978. [CrossRef]

44. Bae, H.J.; Jung, K.H.; Eun, J.W.; Shen, Q.; Kim, H.S.; Park, S.J.; Shin, W.C.; Yang, H.D.; Park, W.S.; Lee, J.Y.; et al. MicroRNA-221 governs tumor suppressor HDAC6 to potentiate malignant progression of liver cancer. J. Hepatol. 2015, 63, 408-419. [CrossRef]

45. Liu, S.; Guo, W.; Shi, J.; Li, N.; Yu, X.; Xue, J.; Fu, X.; Chu, K.; Lu, C.; Zhao, J.; et al. MicroRNA-135a contributes to the development of portal vein tumor thrombus by promoting metastasis in hepatocellular carcinoma. J. Hepatol. 2012, 56, 389-396. [CrossRef] [PubMed]

46. Rybak, A.; Fuchs, H.; Smirnova, L.; Brandt, C.; Pohl, E.E.; Nitsch, R.; Wulczyn, F.G. A feedback loop comprising lin-28 and let-7 controls pre-let-7 maturation during neural stem-cell commitment. Nat. Cell Biol. 2008, 10, 987-993. [CrossRef]

47. Sayed, D.; Rane, S.; Lypowy, J.; He, M.; Chen, I.Y.; Vashistha, H.; Yan, L.; Malhotra, A.; Vatner, D.; Abdellatif, M. MicroRNA-21 targets Sprouty2 and promotes cellular outgrowths. Mol. Biol. Cell 2008, 19, 3272-3282. [CrossRef]

48. Horie, T.; Ono, K.; Nishi, H.; Iwanaga, Y.; Nagao, K.; Kinoshita, M.; Kuwabara, Y.; Takanabe, R.; Hasegawa, K.; Kita, T.; et al. MicroRNA-133 regulates the expression of GLUT4 by targeting KLF15 and is involved in metabolic control in cardiac myocytes. Biochem. Biophys. Res. Commun. 2009, 389, 315-320. [CrossRef]

49. Franco-Zorrilla, J.M.; Valli, A.; Todesco, M.; Mateos, I.; Puga, M.I.; Rubio-Somoza, I.; Leyva, A.; Weigel, D.; Garcia, J.A.; Paz-Ares, J. Target mimicry provides a new mechanism for regulation of microRNA activity. Nat. Genet. 2007, 39, 1033-1037. [CrossRef]

50. Chitwood, D.H.; Timmermans, M.C. Target mimics modulate miRNAs. Nat. Genet. 2007, 39, 935-936. [CrossRef]

51. Ebert, M.S.; Sharp, P.A. MicroRNA sponges: Progress and possibilities. RNA 2010, 16, 2043-2050. [CrossRef] [PubMed]

52. Salmena, L.; Poliseno, L.; Tay, Y.; Kats, L.; Pandolfi, P.P. A ceRNA hypothesis: The Rosetta Stone of a hidden RNA language? Cell 2011, 146, 353-358. [CrossRef] [PubMed]

53. Zhao, L.; Han, T.; Li, Y.; Sun, J.; Zhang, S.; Liu, Y.; Shan, B.; Zheng, D.; Shi, J. The lncRNA SNHG5/miR-32 axis regulates gastric cancer cell proliferation and migration by targeting KLF4. FASEB J. 2017, 31, 893-903. [CrossRef] [PubMed]

54. Zhong, Y.; Du, Y.; Yang, X.; Mo, Y.; Fan, C.; Xiong, F.; Ren, D.; Ye, X.; Li, C.; Wang, Y.; et al. Circular RNAs function as ceRNAs to regulate and control human cancer progression. Mol. Cancer 2018, 17, 79. [CrossRef] [PubMed] 
55. Huang, W.; Huang, F.; Lei, Z.; Luo, H. LncRNA SNHG11 Promotes Proliferation, Migration, Apoptosis, and Autophagy by Regulating hsa-miR-184/AGO2 in HCC. Onco Targets Ther. 2020, 13, 413-421. [CrossRef]

56. Deng, L.; Yang, S.B.; Xu, F.F.; Zhang, J.H. Long noncoding RNA CCAT1 promotes hepatocellular carcinoma progression by functioning as let-7 sponge. J. Exp. Clin. Cancer Res. 2015, 34, 18. [CrossRef]

57. Li, S.; Peng, F.; Ning, Y.; Jiang, P.; Peng, J.; Ding, X.; Zhang, J.; Jiang, T.; Xiang, S. SNHG16 as the miRNA let-7b-5p sponge facilitates the G2/M and epithelial-mesenchymal transition by regulating CDC25B and HMGA2 expression in hepatocellular carcinoma. J. Cell. Biochem. 2020, 121, 2543-2558. [CrossRef]

58. Huang, Y.; Xiang, B.; Liu, Y.; Wang, Y.; Kan, H. LncRNA CDKN2B-AS1 promotes tumor growth and metastasis of human hepatocellular carcinoma by targeting let-7c-5p/NAP1L1 axis. Cancer Lett. 2018, 437, 56-66. [CrossRef]

59. Gong, J.; Wang, J.; Liu, T.; Hu, J.; Zheng, J. lncRNA FEZF1AS1 contributes to cell proliferation, migration and invasion by sponging miR4443 in hepatocellular carcinoma. Mol. Med. Rep. 2018, 18, 5614-5620. [CrossRef]

60. Wei, L.Q.; Li, L.; Lu, C.; Liu, J.; Chen, Y.; Wu, H. Involvement of H19/miR-326 axis in hepatocellular carcinoma development through modulating TWIST1. J. Cell. Physiol. 2019, 234, 5153-5162. [CrossRef]

61. Pan, Y.; Tong, S.; Cui, R.; Fan, J.; Liu, C.; Lin, Y.; Tang, J.; Xie, H.; Lin, P.; Zheng, T.; et al. Long Non-Coding MALAT1 Functions as a Competing Endogenous RNA to Regulate Vimentin Expression by Sponging miR-30a-5p in Hepatocellular Carcinoma. Cell. Physiol. Biochem. 2018, 50, 108-120. [CrossRef] [PubMed]

62. Li, C.; Miao, R.; Liu, S.; Wan, Y.; Zhang, S.; Deng, Y.; Bi, J.; Qu, K.; Zhang, J.; Liu, C. Down-regulation of miR-146b-5p by long noncoding RNA MALAT1 in hepatocellular carcinoma promotes cancer growth and metastasis. Oncotarget 2017, 8, 28683-28695. [CrossRef] [PubMed]

63. Chang, Y.; Zhang, J.; Zhou, C.; Qiu, G.; Wang, G.; Wang, S.; Chang, X.; Li, X.; Fan, L. Long non-coding RNA FOXD2-AS1 plays an oncogenic role in hepatocellular carcinoma by targeting miR206. Oncol. Rep. 2018, 40, 3625-3634. [CrossRef]

64. Hu, M.; Han, Y.; Zhang, Y.; Zhou, Y.; Ye, L. lncRNA TINCR sponges miR-214-5p to upregulate ROCK1 in hepatocellular carcinoma. BMC Med. Genet. 2020, 21, 2. [CrossRef] [PubMed]

65. Dai, W.; Dai, J.L.; Tang, M.H.; Ye, M.S.; Fang, S. lncRNA-SNHG15 accelerates the development of hepatocellular carcinoma by targeting miR-490-3p/ histone deacetylase 2 axis. World J. Gastroenterol. 2019, 25, 5789-5799. [CrossRef]

66. Dong, J.; Teng, F.; Guo, W.; Yang, J.; Ding, G.; Fu, Z. lncRNA SNHG8 Promotes the Tumorigenesis and Metastasis by Sponging miR-149-5p and Predicts Tumor Recurrence in Hepatocellular Carcinoma. Cell. Physiol. Biochem. 2018, 51, 2262-2274. [CrossRef]

67. Zhang, K.; Zhao, Z.; Yu, J.; Chen, W.; Xu, Q.; Chen, L. LncRNA FLVCR1-AS1 acts as miR-513c sponge to modulate cancer cell proliferation, migration, and invasion in hepatocellular carcinoma. J. Cell. Biochem. 2018, 119, 6045-6056. [CrossRef]

68. Li, C.; Lu, L.; Feng, B.; Zhang, K.; Han, S.; Hou, D.; Chen, L.; Chu, X.; Wang, R. The lincRNA-ROR/miR-145 axis promotes invasion and metastasis in hepatocellular carcinoma via induction of epithelial-mesenchymal transition by targeting ZEB2. Sci. Rep. 2017, 7, 4637. [CrossRef]

69. Tu, J.; Zhao, Z.; Xu, M.; Chen, M.; Weng, Q.; Ji, J. LINC00460 promotes hepatocellular carcinoma development through sponging miR-485-5p to up-regulate PAK1. Biomed. Pharmacother. 2019, 118, 109213. [CrossRef]

70. Gao, J.; Yin, X.; Yu, X.; Dai, C.; Zhou, F. Long noncoding RNA LINC00488 functions as a ceRNA to regulate hepatocellular carcinoma cell growth and angiogenesis through miR-330-5. Dig. Liver Dis. 2019, 51, 1050-1059. [CrossRef]

71. Wang, Y.; Sun, L.; Wang, L.; Liu, Z.; Li, Q.; Yao, B.; Wang, C.; Chen, T.; Tu, K.; Liu, Q. Long non-coding RNA DSCR8 acts as a molecular sponge for miR-485-5p to activate Wnt/beta-catenin signal pathway in hepatocellular carcinoma. Cell Death Dis. 2018, 9, 851. [CrossRef] [PubMed]

72. Bao, J.; Chen, X.; Hou, Y.; Kang, G.; Li, Q.; Xu, Y. LncRNA DBH-AS1 facilitates the tumorigenesis of hepatocellular carcinoma by targeting miR-138 via FAK/Src/ERK pathway. Biomed. Pharmacother. 2018, 107, 824-833. [CrossRef] [PubMed]

73. Lv, J.; Kong, Y.; Gao, Z.; Liu, Y.; Zhu, P.; Yu, Z. LncRNA TUG1 interacting with miR-144 contributes to proliferation, migration and tumorigenesis through activating the JAK2/STAT3 pathway in hepatocellular carcinoma. Int. J. Biochem. Cell Biol. 2018, 101, 19-28. [CrossRef] [PubMed] 
74. Lan, T.; Ma, W.; Hong, Z.; Wu, L.; Chen, X.; Yuan, Y. Long non-coding RNA small nucleolar RNA host gene 12 (SNHG12) promotes tumorigenesis and metastasis by targeting miR-199a/b-5p in hepatocellular carcinoma. J. Exp. Clin. Cancer Res. 2017, 36, 11. [CrossRef]

75. Cao, C.; Zhang, T.; Zhang, D.; Xie, L.; Zou, X.; Lei, L.; Wu, D.; Liu, L. The long non-coding RNA, SNHG6-003, functions as a competing endogenous RNA to promote the progression of hepatocellular carcinoma. Oncogene 2017, 36, 1112-1122. [CrossRef]

76. Wang, F.; Ying, H.Q.; He, B.S.; Pan, Y.Q.; Deng, Q.W.; Sun, H.L.; Chen, J.; Liu, X.; Wang, S.K. Upregulated lncRNA-UCA1 contributes to progression of hepatocellular carcinoma through inhibition of miR-216b and activation of FGFR1/ERK signaling pathway. Oncotarget 2015, 6, 7899-7917. [CrossRef]

77. Li, X.; Zhou, Y.; Yang, L.; Ma, Y.; Peng, X.; Yang, S.; Li, H.; Liu, J. LncRNA NEAT1 promotes autophagy via regulating miR-204/ATG3 and enhanced cell resistance to sorafenib in hepatocellular carcinoma. J. Cell. Physiol. 2020, 235, 3402-3413. [CrossRef]

78. Guo, J.; Ma, Y.; Peng, X.; Jin, H.; Liu, J. LncRNA CCAT1 promotes autophagy via regulating ATG7 by sponging miR-181 in hepatocellular carcinoma. J. Cell. Biochem. 2019, 120, 17975-17983. [CrossRef]

79. Yang, L.; Peng, X.; Jin, H.; Liu, J. Long non-coding RNA PVT1 promotes autophagy as ceRNA to target ATG3 by sponging microRNA-365 in hepatocellular carcinoma. Gene 2019, 697, 94-102. [CrossRef]

80. Zhao, L.; Hu, K.; Cao, J.; Wang, P.; Li, J.; Zeng, K.; He, X.; Tu, P.F.; Tong, T.; Han, L. IncRNA miat functions as a ceRNA to upregulate sirt1 by sponging miR-22-3p in HCC cellular senescence. Aging 2019, 11, 7098-7122. [CrossRef]

81. Xiang, Y.; Huang, Y.; Sun, H.; Pan, Y.; Wu, M.; Zhang, J. Deregulation of miR-520d-3p promotes hepatocellular carcinoma development via lncRNA MIAT regulation and EPHA2 signaling activation. Biomed. Pharmacother. 2019, 109, 1630-1639. [CrossRef] [PubMed]

82. Wang, C.; Ke, S.; Li, M.; Lin, C.; Liu, X.; Pan, Q. Downregulation of LncRNA GAS5 promotes liver cancer proliferation and drug resistance by decreasing PTEN expression. Mol. Genet. Genom. 2020, 295, 251-260. [CrossRef] [PubMed]

83. Xu, F.; Zha, G.; Wu, Y.; Cai, W.; Ao, J. Overexpressing lncRNA SNHG16 inhibited HCC proliferation and chemoresistance by functionally sponging hsa-miR-93. Onco Targets Ther. 2018, 11, 8855-8863. [CrossRef] [PubMed]

84. Zhang, Y.; Zhu, Z.; Huang, S.; Zhao, Q.; Huang, C.; Tang, Y.; Sun, C.; Zhang, Z.; Wang, L.; Chen, H.; et al. lncRNA XIST regulates proliferation and migration of hepatocellular carcinoma cells by acting as miR-497-5p molecular sponge and targeting PDCD4. Cancer Cell. Int. 2019, 19, 198. [CrossRef] [PubMed]

85. Wang, Y.G.; Wang, T.; Shi, M.; Zhai, B. Long noncoding RNA EPB41L4A-AS2 inhibits hepatocellular carcinoma development by sponging miR-301a-5p and targeting FOXL1. J. Exp. Clin. Cancer Res. 2019, 38, 153. [CrossRef]

86. Wang, Y.G.; Liu, J.; Shi, M.; Chen, F.X. LncRNA DGCR5 represses the development of hepatocellular carcinoma by targeting the miR-346/KLF14 axis. J. Cell. Physiol. 2018, 234, 572-580. [CrossRef]

87. Yan, S.; Tang, Z.; Chen, K.; Liu, Y.; Yu, G.; Chen, Q.; Dang, H.; Chen, F.; Ling, J.; Zhu, L.; et al. Long noncoding RNA MIR31HG inhibits hepatocellular carcinoma proliferation and metastasis by sponging microRNA-575 to modulate ST7L expression. J. Exp. Clin. Cancer Res. 2018, 37, 214. [CrossRef]

88. Hu, B.; Cai, H.; Zheng, R.; Yang, S.; Zhou, Z.; Tu, J. Long non-coding RNA 657 suppresses hepatocellular carcinoma cell growth by acting as a molecular sponge of miR-106a-5p to regulate PTEN expression. Int. J. Biochem. Cell Biol. 2017, 92, 34-42. [CrossRef]

89. Wang, Y.; Liu, Z.; Yao, B.; Dou, C.; Xu, M.; Xue, Y.; Ding, L.; Jia, Y.; Zhang, H.; Li, Q.; et al. Long non-coding RNA TUSC7 acts a molecular sponge for miR-10a and suppresses EMT in hepatocellular carcinoma. Tumor Biol. 2016, 37, 11429-11441. [CrossRef]

90. Li, Y.; Shi, H.; Yuan, J.; Qiao, L.; Dong, L.; Wang, Y. Downregulation of circular RNA circPVT1 restricts cell growth of hepatocellular carcinoma through downregulation of Sirtuin 7 via microRNA-3666. Clin. Exp. Pharmacol. Physiol. 2020. [CrossRef]

91. Chen, J.; Li, Y.; Zheng, Q.; Bao, C.; He, J.; Chen, B.; Lyu, D.; Zheng, B.; Xu, Y.; Long, Z.; et al. Circular RNA profile identifies circPVT1 as a proliferative factor and prognostic marker in gastric cancer. Cancer Lett. 2017, 388, 208-219. [CrossRef]

92. Wang, Z.; Su, M.; Xiang, B.; Zhao, K.; Qin, B. Circular RNA PVT1 promotes metastasis via miR-145 sponging in CRC. Biochem. Biophys. Res. Commun. 2019, 512, 716-722. [CrossRef] [PubMed] 
93. Qin, S.; Zhao, Y.; Lim, G.; Lin, H.; Zhang, X.; Zhang, X. Circular RNA PVT1 acts as a competing endogenous RNA for miR-497 in promoting non-small cell lung cancer progression. Biomed. Pharmacother. 2019, 111, 244-250. [CrossRef] [PubMed]

94. Xiao, Y.; Liu, G.; Sun, Y.; Gao, Y.; Ouyang, X.; Chang, C.; Gong, L.; Yeh, S. Targeting the estrogen receptor alpha (ERalpha)-mediated circ-SMG1.72/miR-141-3p/Gelsolin signaling to better suppress the HCC cell invasion. Oncogene 2020, 39, 2493-2508. [CrossRef] [PubMed]

95. Huang, X.Y.; Huang, Z.L.; Xu, Y.H.; Zheng, Q.; Chen, Z.; Song, W.; Zhou, J.; Tang, Z.Y.; Huang, X.Y. Comprehensive circular RNA profiling reveals the regulatory role of the circRNA-100338/miR-141-3p pathway in hepatitis B-related hepatocellular carcinoma. Sci. Rep. 2017, 7, 5428. [CrossRef]

96. Wu, J.; Liu, S.; Xiang, Y.; Qu, X.; Xie, Y.; Zhang, X. Bioinformatic Analysis of Circular RNA-Associated ceRNA Network Associated with Hepatocellular Carcinoma. BioMed Res. Int. 2019, 2019, 8308694. [CrossRef]

97. Wei, Y.; Chen, X.; Liang, C.; Ling, Y.; Yang, X.; Ye, X.; Zhang, H.; Yang, P.; Cui, X.; Ren, Y.; et al. A Noncoding Regulatory RNAs Network Driven by Circ-CDYL Acts Specifically in the Early Stages Hepatocellular Carcinoma. Hepatology 2020, 71, 130-147. [CrossRef]

98. Qi, S.X.; Sun, H.; Liu, H.; Yu, J.; Jiang, Z.Y.; Yan, P. Role and mechanism of circ-PRKCI in hepatocellular carcinoma. World J. Gastroenterol. 2019, 25, 1964-1974. [CrossRef]

99. Xie, B.; Zhao,_Z.; Liu, Q.; Wang, X.; Ma,ZZ; Li, H. CircRNA has_circ_0078710 acts as the sponge of microRNA-31 involved in hepatocellular carcinoma progression. Gene 2019, 683, 253-261. [CrossRef]

100. Liu, H.; Xue, L.; Song, C.; Liu, F.; Jiang, T.; Yang, X. Overexpression of circular RNA circ_001569 indicates poor prognosis in hepatocellular carcinoma and promotes cell growth and metastasis by sponging miR-411-5p and miR-432-5p. Biochem. Biophys. Res. Commun. 2018, 503, 2659-2665. [CrossRef]

101. Li, M.F.; Li, Y.H.; He, Y.H.; Wang, Q.; Zhang, Y.; Li, X.F.; Meng, X.M.; Huang, C.; Li, J. Emerging roles of hsa_circ_0005075 targeting miR-431 in the progress of HCC. Biomed. Pharmacother. 2018, 99, 848-858. [CrossRef] [PubMed]

102. Bai, N.; Peng, E.; Qiu, X.; Lyu, N.; Zhang, Z.; Tao, Y.; Li, X.; Wang, Z. circFBLIM1 act as a ceRNA to promote hepatocellular cancer progression by sponging miR-346. J. Exp. Clin. Cancer Res. 2018, 37, 172. [CrossRef] [PubMed]

103. Chen, G.; Shi, Y.; Liu, M.; Sun, J. circHIPK3 regulates cell proliferation and migration by sponging miR-124 and regulating AQP3 expression in hepatocellular carcinoma. Cell Death Dis. 2018, 9, 175. [CrossRef] [PubMed]

104. Tian, F.; Yu, C.; Wu, M.; Wu, X.; Wan, L.; Zhu, X. MicroRNA-191 promotes hepatocellular carcinoma cell proliferation by has_circ_0000204/miR-191/KLF6 axis. Cell Prolif. 2019, 52, e12635. [CrossRef]

105. Wang, Z.; Zhao, Y.; Wang, Y.; Jin, C. Circular RNA circHIAT1 inhibits cell growth in hepatocellular carcinoma by regulating miR-3171/PTEN axis. Biomed. Pharmacother. 2019, 116, 108932. [CrossRef]

106. Xu, L.; Feng, X.; Hao, X.; Wang, P.; Zhang, Y.; Zheng, X.; Li, L.; Ren, S.; Zhang, M.; Xu, M. CircSETD3 (Hsa_circ_0000567) acts as a sponge for microRNA-421 inhibiting hepatocellular carcinoma growth. J. Exp. Clin. Cancer Res. 2019, 38, 98. [CrossRef]

107. Qiu, L.; Huang, Y.; Li, Z.; Dong, X.; Chen, G.; Xu, H.; Zeng, Y.; Cai, Z.; Liu, X.; Liu, J. Circular RNA profiling identifies circADAMTS13 as a miR-484 sponge which suppresses cell proliferation in hepatocellular carcinoma. Mol. Oncol. 2019, 13, 441-455. [CrossRef]

108. Han, D.; Li, J.; Wang, H.; Su, X.; Hou, J.; Gu, Y.; Qian, C.; Lin, Y.; Liu, X.; Huang, M.; et al. Circular RNA circMTO1 acts as the sponge of microRNA-9 to suppress hepatocellular carcinoma progression. Hepatology 2017, 66, 1151-1164. [CrossRef]

109. Fu, L.; Chen, Q.; Yao, T.; Li, T.; Ying, S.; Hu, Y.; Guo, J. Hsa_circ_0005986 inhibits carcinogenesis by acting as a miR-129-5p sponge and is used as a novel biomarker for hepatocellular carcinoma. Oncotarget 2017, 8, 43878-43888. [CrossRef]

110. Chen, S.; Zhang, Y.; Wu, X.; Zhang, C.; Li, G. Diagnostic Value of lncRNAs as Biomarker in Hepatocellular Carcinoma: An Updated Meta-Analysis. Can. J. Gastroenterol. Hepatol. 2018, 2018, 8410195. [CrossRef]

111. Li, G.; Shi, H.; Wang, X.; Wang, B.; Qu, Q.; Geng, H.; Sun, H. Identification of diagnostic long noncoding RNA biomarkers in patients with hepatocellular carcinoma. Mol. Med. Rep. 2019, 20, 1121-1130. [CrossRef] [PubMed]

112. Chen, F.; Li, Y.; Li, M.; Wang, L. Long noncoding RNA GAS5 inhibits metastasis by targeting miR-182/ANGPTL1 in hepatocellular carcinoma. Am. J. Cancer Res. 2019, 9, 108-121. 
113. Han, M.H.; Lee, J.H.; Kim, G.; Lee, E.; Lee, Y.R.; Jang, S.Y.; Lee, H.W.; Chun, J.M.; Han, Y.S.; Yoon, J.S.; et al. Expression of the Long Noncoding RNA GAS5 Correlates with Liver Fibrosis in Patients with Nonalcoholic Fatty Liver Disease. Genes 2020, 11, 545. [CrossRef] [PubMed]

114. Hu, L.; Ye, H.; Huang, G.; Luo, F.; Liu, Y.; Liu, Y.; Yang, X.; Shen, J.; Liu, Q.; Zhang, J. Long noncoding RNA GAS5 suppresses the migration and invasion of hepatocellular carcinoma cells via miR-21. Tumour Biol. 2016, 37, 2691-2702. [CrossRef] [PubMed]

115. Tu, Z.Q.; Li, R.J.; Mei, J.Z.; Li, X.H. Down-regulation of long non-coding RNA GAS5 is associated with the prognosis of hepatocellular carcinoma. Int. J. Clin. Exp. Pathol. 2014, 7, 4303-4309.

116. Wang, J.; Liu, X.; Wu, H.; Ni, P.; Gu, Z.; Qiao, Y.; Chen, N.; Sun, F.; Fan, Q. CREB up-regulates long non-coding RNA, HULC expression through interaction with microRNA-372 in liver cancer. Nucleic Acids Res. 2010, 38, 5366-5383. [CrossRef]

117. Wang, Y.; Chen, F.; Zhao, M.; Yang, Z.; Li, J.; Zhang, S.; Zhang, W.; Ye, L.; Zhang, X. The long noncoding RNA HULC promotes liver cancer by increasing the expression of the HMGA2 oncogene via sequestration of the microRNA-186. J. Biol. Chem. 2017, 292, 15395-15407. [CrossRef]

118. Li, J.; Wang, X.; Tang, J.; Jiang, R.; Zhang, W.; Ji, J.; Sun, B. HULC and Linc00152 Act as Novel Biomarkers in Predicting Diagnosis of Hepatocellular Carcinoma. Cell. Physiol. Biochem. 2015, 37, 687-696. [CrossRef]

119. Konishi, H.; Ichikawa, D.; Yamamoto, Y.; Arita, T.; Shoda, K.; Hiramoto, H.; Hamada, J.; Itoh, H.; Fujita, Y.; Komatsu, S.; et al. Plasma level of metastasis-associated lung adenocarcinoma transcript 1 is associated with liver damage and predicts development of hepatocellular carcinoma. Cancer Sci. 2016, 107, 149-154. [CrossRef]

120. Zheng, Z.K.; Pang, C.; Yang, Y.; Duan, Q.; Zhang, J.; Liu, W.C. Serum long noncoding RNA urothelial carcinoma-associated 1: A novel biomarker for diagnosis and prognosis of hepatocellular carcinoma. J. Int. Med. Res. 2018, 46, 348-356. [CrossRef]

121. Roberts, L.R. Current Status of the GALAD and BALAD Biomarker Models for Hepatocellular Carcinoma. Gastroenterol. Hepatol. 2019, 15, 672-675.

122. Best, J.; Bechmann, L.P.; Sowa, J.P.; Sydor, S.; Dechene, A.; Pflanz, K.; Bedreli, S.; Schotten, C.; Geier, A.; Berg, T.; et al. GALAD Score Detects Early Hepatocellular Carcinoma in an International Cohort of Patients With Nonalcoholic Steatohepatitis. Clin. Gastroenterol. Hepatol. 2020, 18, 728-735. [CrossRef] [PubMed]

123. Shang, X.; Li, G.; Liu, H.; Li, T.; Liu, J.; Zhao, Q.; Wang, C. Comprehensive Circular RNA Profiling Reveals That hsa_circ_0005075, a New Circular RNA Biomarker, Is Involved in Hepatocellular Crcinoma Development. Medicine 2016, 95, e3811. [CrossRef]

124. Jin, Y.D.; Ren, Y.R.; Gao, Y.X.; Zhang, L.; Ding, Z. Hsa_circ_0005075 predicts a poor prognosis and acts as an oncogene in colorectal cancer via activating Wnt/beta-catenin pathway. Eur. Rev. Med. Pharmacol. Sci. 2019, 23, 3311-3319. [CrossRef] [PubMed]

125. Chen, D.; Zhang, C.; Lin, J.; Song, X.; Wang, H. Screening differential circular RNA expression profiles reveal that hsa_circ_0128298 is a biomarker in the diagnosis and prognosis of hepatocellular carcinoma. Cancer Manag. Res. 2018, 10, 1275-1283. [CrossRef]

126. Fu, L.; Yao, T.; Chen, Q.; Mo, X.; Hu, Y.; Guo, J. Screening differential circular RNA expression profiles reveals hsa_circ_0004018 is associated with hepatocellular carcinoma. Oncotarget 2017, 8, 58405-58416. [CrossRef]

127. Wang, M.; Gu, B.; Yao, G.; Li, P.; Wang, K. Circular RNA Expression Profiles and the Pro-tumorigenic Function of CircRNA_10156 in Hepatitis B Virus-Related Liver Cancer. Int. J. Med. Sci. 2020, 17, 1351-1365. [CrossRef]

128. Memczak, S.; Papavasileiou, P.; Peters, O.; Rajewsky, N. Identification and Characterization of Circular RNAs As a New Class of Putative Biomarkers in Human Blood. PLoS ONE 2015, 10, e0141214. [CrossRef]

129. Mehinovic, L.; Islamagic, E.; Husic-Selimovic, A.; Kurtovic-Kozaric, A.; Vukobrat-Bijedic, Z.; Suljevic, D. Evaluation of Diagnostic Efficiency of Alpha-Fetoprotein in Patients with Liver Cirrhosis and Hepatocellular Carcinoma: Single-Center Experience. Open Access Maced. J. Med. Sci. 2018, 6, 1668-1673. [CrossRef]

130. Li, Y.; Zheng, Q.; Bao, C.; Li, S.; Guo, W.; Zhao, J.; Chen, D.; Gu, J.; He, X.; Huang, S. Circular RNA is enriched and stable in exosomes: A promising biomarker for cancer diagnosis. Cell Res. 2015, 25, 981-984. [CrossRef]

131. Dai, X.; Chen, C.; Yang, Q.; Xue, J.; Chen, X.; Sun, B.; Luo, F.; Liu, X.; Xiao, T.; Xu, H.; et al. Exosomal circRNA_100284 from arsenite-transformed cells, via microRNA-217 regulation of EZH2, is involved in the malignant transformation of human hepatic cells by accelerating the cell cycle and promoting cell proliferation. Cell Death Dis. 2018, 9, 454. [CrossRef] 
132. Wang, G.; Liu, W.; Zou, Y.; Wang, G.; Deng, Y.; Luo, J.; Zhang, Y.; Li, H.; Zhang, Q.; Yang, Y.; et al. Three isoforms of exosomal circPTGR1 promote hepatocellular carcinoma metastasis via the miR449a-MET pathway. EBioMedicine 2019, 40, 432-445. [CrossRef] [PubMed]

133. Zhang, H.; Deng, T.; Ge, S.; Liu, Y.; Bai, M.; Zhu, K.; Fan, Q.; Li, J.; Ning, T.; Tian, F.; et al. Exosome circRNA secreted from adipocytes promotes the growth of hepatocellular carcinoma by targeting deubiquitination-related USP7. Oncogene 2019, 38, 2844-2859. [CrossRef] [PubMed]

134. Tang, W.; Chen, Z.; Zhang, W.; Cheng, Y.; Zhang, B.; Wu, F.; Wang, Q.; Wang, S.; Rong, D.; Reiter, F.P.; et al. The mechanisms of sorafenib resistance in hepatocellular carcinoma: Theoretical basis and therapeutic aspects. Signal Transduct. Target. Ther. 2020, 5, 87. [CrossRef] [PubMed]

135. Jin, W.; Chen, L.; Cai, X.; Zhang, Y.; Zhang, J.; Ma, D.; Cai, X.; Fu, T.; Yu, Z.; Yu, F.; et al. Long non-coding RNA TUC338 is functionally involved in sorafenib-sensitized hepatocarcinoma cells by targeting RASAL1. Oncol. Rep. 2017, 37, 273-280. [CrossRef]

136. Takahashi, K.; Yan, I.K.; Wood, J.; Haga, H.; Patel, T. Involvement of extracellular vesicle long noncoding RNA (linc-VLDLR) in tumor cell responses to chemotherapy. Mol. Cancer Res. 2014, 12, 1377-1387. [CrossRef] [PubMed]

137. Wu, M.Y.; Tang, Y.P.; Liu, J.J.; Liang, R.; Luo, X.L. Global transcriptomic study of circRNAs expression profile in sorafenib resistant hepatocellular carcinoma cells. J. Cancer 2020, 11, 2993-3001. [CrossRef]

138. Gao, Y.; Wang, J.; Zhao, F. CIRI: An efficient and unbiased algorithm for de novo circular RNA identification. Genome Biol. 2015, 16, 4. [CrossRef]

139. Gao, Y.; Zhang, J.; Zhao, F. Circular RNA identification based on multiple seed matching. Brief. Bioinform. 2018, 19, 803-810. [CrossRef]

(C) 2020 by the authors. Licensee MDPI, Basel, Switzerland. This article is an open access article distributed under the terms and conditions of the Creative Commons Attribution (CC BY) license (http://creativecommons.org/licenses/by/4.0/). 